\title{
A Review of Acid Mine Drainage in a Water-Scarce Country: Case of South Africa
}

\author{
Joseph Kapuku Bwapwa \\ Mangosuthu University of Technology, Engineering faculty \\ P.O Box 12363, Jacobs 4026, Umlazi, Durban, South Africa \\ E-mail: josephkapuku@gmail.com
}

Received: August 18, 2017 Accepted: September 12, 2017

doi:10.5296/emsd.v7i1.12125 URL: https://doi.org/10.5296/emsd.v7i1.12125

\begin{abstract}
Acid mine drainage (AMD) is a very acidic effluent containing high levels of sulphates, metals, sulphides, and salts. AMD management requires particular attention in order to avoid environmental adversity. Currently, there is a tremendous need for new technologies, effective management strategies and treatment processes regarding AMD in South Africa and worldwide. This includes the development of nearly zero waste processes. AMD in South Africa and many countries worldwide involves massive environmental issues that cannot be solved in the short to medium term. To address this problem much effort is required to develop efficient, innovative and costs effective methods to resolve the challenge of AMD. This review analyzes some major active treatment technologies and management options for AMD reclamation. It is also including some technical and economic strengths as well as setbacks related to some treatment methods.
\end{abstract}

Keywords: Acid mine drainage (AMD), Water scarcity, Ecosystems, Mine water, Mine water management

CAPSULE: Acid mine drainage can treated using physical, chemical and biological methods with high recovery output

\section{Introduction}

\subsection{Background}

Acid mine drainage (AMD) has generally a pH varying between 2 and 3 or lower than 7 in many cases and contains important concentrations or levels of heavy metals (Diz, 1997; Bigham and Cravotta, 2016 ). These concentrations are the result of biological and chemical weathering of sulphide minerals especially marcasite $\left(\mathrm{FeS}_{2}\right)$, pyrite, pyrrhotite $\left(\mathrm{Fe}_{1-\mathrm{x}} \mathrm{S}\right)$ and 
chalcopyrite $\left(\mathrm{CuFeS}_{2}\right)$. Chemical and biological reactions lead to the production of sulphuric acid with metal ions being released (Diz, 1997; Bigham and Cravotta, 2016). There are also organisms that exist in AMDs which can survive extreme acidic conditions such as Thiobacillus ferrooxidans and can thrive in $\mathrm{pH}$ ranging from 1.5 to 3.5 (Mühling et al., 2016; Chen et al., 2016). When microorganisms are present in AMD, the production of sulphuric acid occurs at a much higher rate since certain microorganisms obtain crucial energy from the oxidation of ferrous iron (Mühling et al., 2016; Kuang et al., 2016; Chen et al., 2016). It is therefore important to evaluate cost effective measures for the removal of pollutants from contaminated sites in order to have safe drinking and useful water resources for the communities in need (Diz, 1997). Jennings et al.,(2008) suggested that when designing and implementing any AMD treatment system, surface runoff and groundwater will have to be intercepted by using ditches and cut-off walls respectively to make the system effective. This action should be undertaken in order to prevent the dispersion of surface water into the system which may reduce the concentration of iron, limestone and other essential catalysts for the processes (Akcil and Koldas, 2006).

The issue of AMD was raised and reported in many areas within South Africa. They are many affected areas and the most known are: Witwatersrand Gold Fields, Mpumalanga and KwaZulu-Natal Coal Fields and the O'Kiep Copper District. However, some areas are identified as critical and they are given first priority because of the major environmental impacts caused by AMD in those areas. They include the Western, Central and Eastern Basins. An urgent attention and actions are needed to reduce the effects caused by high volume of contaminated effluents. The current situation is caused by the lack of adequate management strategies to control the flooding and environmental destruction. Furthermore, monitoring and assessment of risks, mostly in vulnerable areas including Mpumalanga Coal Fields are needed. In these areas the impact of mining on freshwater resources in the upper reaches the Vaal and Olifants Rivers. Risks owing to the decant of AMD, flooding in low altitude areas were identified with respect to the flooding of the mines in the priority areas and the subsequent decant of AMD to the environment causing negative ecological impacts.

\subsection{Formation of AMD: Acidification and Contamination in Mine Voids}

AMD is formed in mining environments, ore and waste materials with sulphide minerals such as pyrite, are exposed to water and oxygen. Pyrite $\left(\mathrm{FeS}_{2}\right)$ is responsible for starting acid generation and metals dissolution in coal and hard rock (Pak et al., 2016; Water, 2016; Bigham and Cravotta, 2016). Equation 1 shows that when pyrite is exposed to oxygen and water it get oxidized, resulting in hydrogen ion release (source of acidity), sulphate ions, and soluble ferrous iron cations. This reaction of oxidation occurs at slow rate in undisturbed rock and the water is able to buffer the acid generated during the reaction. Mining increases the exposed surface area of these sulphur-bearing rocks allowing for excess acid generation beyond the water's natural buffering capabilities. The following chemical reactions from (1) to (4) summarize the formation of AMD from stormwater and oxygen weathering pyrite.

$$
\mathrm{FeS}_{2}+7 / 2 \mathrm{O}_{2}+\mathrm{H}_{2} \mathrm{O} \rightarrow \mathrm{Fe}^{+2}+2 \mathrm{SO}_{4}^{-2}+2 \mathrm{H}^{+}
$$




$$
\begin{gathered}
\mathrm{Fe}^{+2}+1 / 4 \mathrm{O}_{2}+\mathrm{H}^{+} \rightarrow \mathrm{Fe}^{+3}+1 / 2 \mathrm{H}_{2} \mathrm{O} \\
\mathrm{Fe}^{+3}+3 \mathrm{H}_{2} \mathrm{O} \rightarrow \mathrm{Fe}(\mathrm{OH})_{3}+3 \mathrm{H}^{+} \\
\mathrm{FeS}_{2}+14 \mathrm{Fe}^{+3}+8 \mathrm{H}_{2} \mathrm{O} \rightarrow 15 \mathrm{Fe}^{+2}+2 \mathrm{SO}_{4}^{-2}+16 \mathrm{H}^{+}
\end{gathered}
$$

When ferrous iron is produced from equation 4 and sufficient dissolved oxygen is present, the cycle of equations 2 and 3 is perpetuated (Younger, et al., 2002; Pak et al.,2016). Without dissolved oxygen, equation 4 will continue to the completion and water will show elevated levels of ferrous iron (Younger, et al, 2002; Pak et al., 2016). Once the waters are sufficiently acidic, acidophilic bacteria (bacteria that thrive in low $\mathrm{pH}$ ) will be able to establish themselves. Microorganisms can play a significant role in accelerating chemical reactions taking place in mine drainage conditions. Thiobacillus ferroxidans bacteria, is commonly referenced in this case. These bacteria catalyse the oxidation of ferrous iron, therefore, perpetuating the equations 2, 3 and 4. Another microorganism named Ferroplasma acidarmanus plays a significant role in the production of acidity in mine waters (Lauzon, 2000).

The objective of the current review is to analyse major active treatment technologies and management options for AMD reclamation. This aims to establish technological and economic strengths as well as setbacks related to some treatment methods. The study will serve as a guide amongst other for future studies to improve or build on existing and sustainable processes regarding the issue of AMD.

\section{Few Examples of International AMD Management Strategies: Overview}

\subsection{Acid Mine Drainage in Australia}

An environmental guideline for operating mines in Australia was published in 1995 by the Australian and New Zealand Mineral and Energy Council (ANZMEC). It is mentioned in the guideline that AMD should be predicted and included in the mine closure plan (ANZMEC, 1995). To understand better the impact of AMD in Australia and to provide the basis allowing to assess options for AMD management, there was a preparation of a status report on AMD initiated by Supervising Scientist and the Australian Centre for Minesite Rehabilitation Research (Harries, 1997). This report has laid down the work done previously and different strategies for the future to deal efficiently with AMD in Australia. This issue of AMD in the country seems to be handled effectively based on the fact that mines are amongst the major contributors to the country's economy.

\subsection{Acid Mine Drainage in Canada}

A programme named Canadian Mine Environment Neutral Drainage (MEND) was established by mine agencies in 1989. The objective of the programme was to respond to the issue of AMD recognition as the leading environmental concern faced by the Canadian mining industry. The Mining sector in Canada was required to establish trust funds for the covering of the costs related to the effect of AMD from mine wastes. It was reported in a 
survey of metal-mine and industrial-mineral tailings held in 1994 that from a total of 7 billion tons of tailings and 6 billion tons of waste rock only 1.9 billion tons of tailings and 750 million tons of waste rock were described as potentially acid generating material (MEND, 1995). The Canadian mining sector together with the environment and the mining corporations are most of the time involved in regulating the issue of AMD in order to protect the environment and human lives. The issue of AMD in the Canadian context is very regulated and controlled to avoid more damages to the environment.

\subsection{Acid Mine Drainage in the United States of America}

In the USA the main AMD problem identified was the impact of acid drainage from coal mines on freshwater resources situated in the eastern part of the United States. Almost 7000 $\mathrm{km}$ of freshwater resources were affected (Ferguson and Erickson, 1988). Generally, between 8000 and $16000 \mathrm{~km}$ of freshwater in the USA are affected by AMD (USEPA, 1995). AMD from abandoned mines are the major cause of this problem. However, in the USA abandoned mines are rehabilitated under the National Abandoned Mine Land Programme. This is under the Office of Surface Mining Reclamation and Enforcement (OSMRE). Funds are raised via a levy on active coal mines and deposited into the Abandoned Mine Lands (AML) fund a trust administered by the U.S. Treasury (Office of Surface Mining, 2006) to pay for reclamation of mines abandoned before the passage of the Surface Mining Control and Reclamation Act of 1977

\section{Comparison of International Examples with the South African Context}

The main aspects distinguishing the AMD problem in South Africa from the international examples mentioned before are the extent of interconnection of large mine voids and the fact that affected areas are situated either in or close to major cities. Furthermore, a large number of abandoned mines are still not given attention for effective effluent management to reduce the impact of AMD in affected areas.

The problem requires large-scale programmes and effective strategies to address the AMD issue. In some few countries, planning of mine flooding is undertaken effectively in order to reduce significantly the impacts. Consequently, the ecological concerns can be reduced.

In South Africa the environmental concern caused by AMD was intensified by the premature closure of old and abandoned mines situated within the basins. The international experience has revealed there are factors leading to successful implementation of strategies when dealing with AMD. These factors include the following aspects:

- Recognition of AMD problem which needs to be clearly identified and properly and continuously addressed in a coordinated programme between government and the mining industry

- Synchronisation between stakeholders with government playing the leading role

- Continuous research to provide innovative, costs effective, optimal and sustainable solutions. 


\section{Risk Management Measures}

Risk management measures to reduce the impacts of AMD can be based on simple management strategies (DWAF, 2006; Macías et al., 2017; Jones and Cetin, 2017 ; Water, 2016).

The strategies involve the following:

-Decant prevention and management: this is very important because its helps reduce the risk of seismic activity and monitor the volume of AMD in mine voids. It will require to maintain water level below the Environmental Critical Level for the basin. Pumping of water from the mine void is indispensable.

-Ingress control: allowing the reduction of the flooding rate and the eventual decant

Volume

-AMD quality management: The quality of AMD in the mine voids is of poor quality, with low $\mathrm{pH}$, high acidity and elevated concentrations of sulphates, iron and other metals (Fernandes, 2016). Therefore, it is imperative to check regularly the quality of AMD in order to predict and assess the level of contamination and its impacts in the environment when discharged.

\section{Management Strategy Steps}

Proper AMD management strategy should include the following steps (DWAF, 2006; Macías et al., 2017; Water, 2016; Fernandes, 2016)

Step 1: Pollution prevention: to reduce the negative impacts on the receiving environment.

Step 2: Minimisation of impacts: to maximize the option of water reuse and reclamation this deals with effective water treatment options (Jones and Cetin, 2017; Water, 2016).

Step 3: Discharge or disposal of waste and/or wastewater: Site-specific risk based approach. Dealing with the best options for discharge that are costs effective and sustainable (Demers et al., 2017; Jones and Cetin, 2017; Water, 2016).

These steps represents the hierarchy of actions and decisive options needed for an effective management of AMD in many countries including South Africa.

\section{Work Done, Actions to be Taken and Knowledge Gaps}

Many studies have been undertaken by a great number of institutions in South Africa on the nature and extent of the AMD issue. They have suggested a number of measures to alleviate the environmental impact related to AMD discharge. In many cases, studies have developed measures to better manage and prevent AMD formation. More importantly, these studies have developed technologies to treat AMD, however, there is still a need for innovation and improvements. Institutions such as the Council for Scientific and Industrial Research (CSIR), Mintek, the Water Research Commission (WRC) and the department of water affairs and forestry (DWAF) have been seriously involved in AMD issues in order to tackle the 
environmental challenges related to AMD. Although there is still more to do, currently, there is sufficient knowledge regarding the origin of AMD, potential impacts, management strategies and treatment technologies. The knowledge can help for the prediction of various environmental impacts caused by AMD discharge. Furthermore, it can help for data analysis and monitoring which are essential to minimise uncertainties that can exist in the current predictive models, although more research is still needed to minimise uncertainties and to develop sustainable solutions for the medium to long term. The creation of an effective legal framework and policy management to facilitate the beneficiation of AMD constitutes a gap that needs to be filled. Furthermore, the identification all the mines which are not operational but generating AMD will be an important step toward effective management. Once those abandoned mines are identified provisional management measures such as storage of AMD in dams will be taken before the implementation of effective treatment process.

\section{Impact of Acid Mine Drainage on the Quality of Fresh Water Resources in South Africa}

South Africa mines coal, gold, diamonds, platinum, palladium and chromium since the beginning of the $20^{\text {th }}$ century. South African mines are amongst the largest in the world with a capacity to hold large volumes of contaminated water. This may constitute a massive environmental and health potential hazard (Bell et al., 2001; Demers , 2017 ; water , 2016 ). When rain water fills the mines, it creates acid drainage causing contamination to the groundwater and local rivers. Consequently, the aquatic life is potentially at risk, the vegetation on the surroundings are being damaged, the soil is contaminated, and eventually, the costs of treatment can be significantly increased. Generally, AMD causes countless damages to water resources such as surface streams and groundwater in South Africa and worldwide. It is a serious cause for concern since the country relies on surface streams and rainwater to supply water for drinking and domestic activities to the communities. The high levels of gold and coal mining in the country coupled with the lack of appropriate strategies to prevent contamination are major contributing factors to the current disastrous situation in some parts of the country (Water, 2016). Furthermore, the poor quality of large amounts of water accumulated in the mine voids with relatively very low $\mathrm{pH}$, high acidity, high sulphate concentrations, iron, other heavy metals and dissolved solids is also a great contributor to contamination. It is also important to emphasis on the fact that a large number of abandoned mines are not monitored properly or prevention measures are not applied rigorously or they are not efficient enough to be sustainable. Consequently, the contamination of surface and groundwater becomes a great challenge technically and economically (Water, 2016). Figure 1 presents various locations for coal, base and precious metals mining. It indicates how mining activities are spread all over the country and it can be possible to predict the economic benefits and environmental impacts of these mines in the near future. The central basin (north and central part of the country), the eastern basin (eastern part of the country) and the western basin (western part of the country) are identified as the 3 main sites where mining activities have a high environmental impact on fresh water resources (Naidoo, 2017). On these sites significant volumes of effluents are generated, they constitute a permanent hazard for natural resources such as rivers and lakes (Naidoo, 2017). 


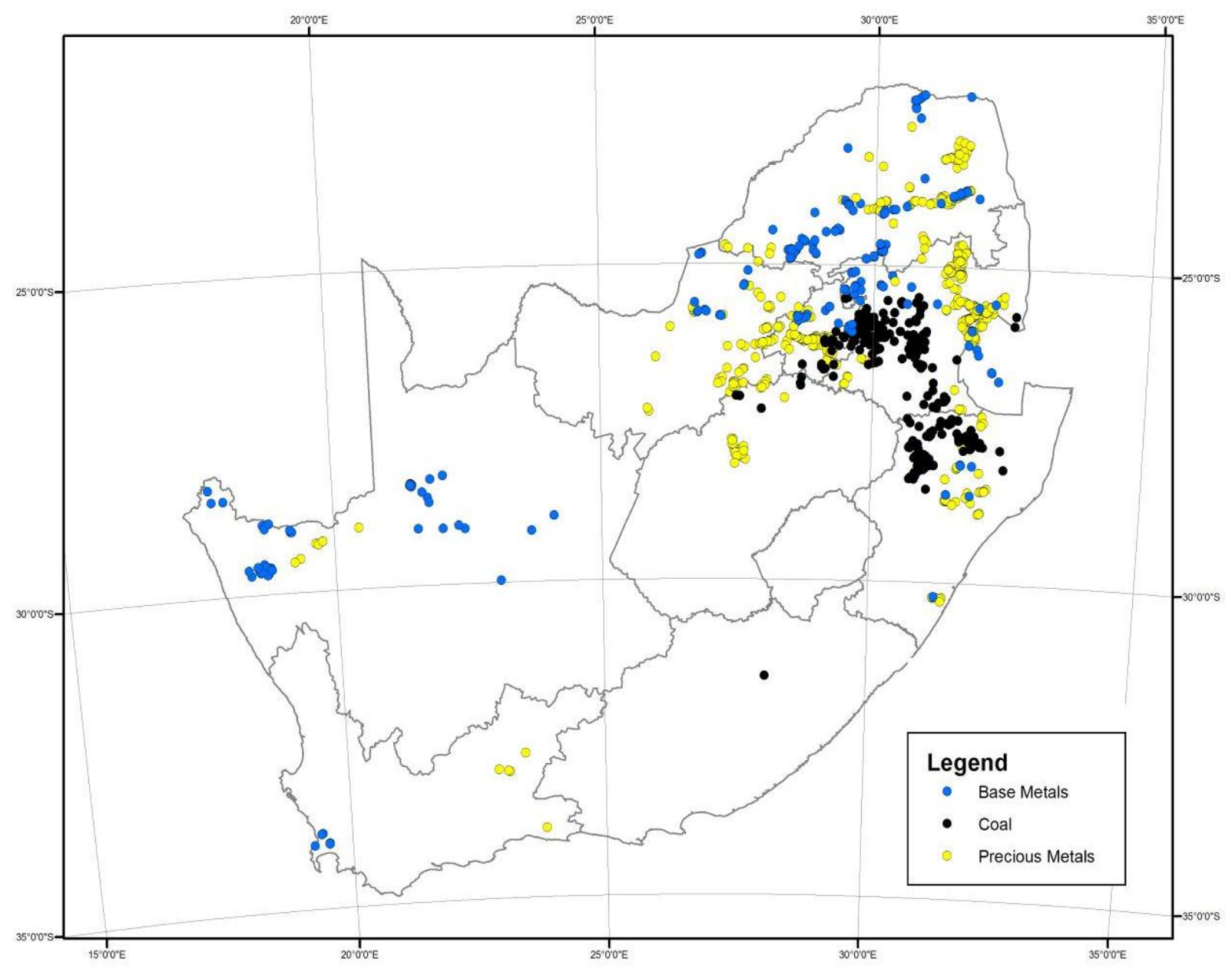

Figure 1. Potentially AMD Producing Mines in South Africa (source: Water affairs)

\section{Water Scarcity in South Africa and AMD Contribution}

South Africa is categorized as water-stressed country with an annual fresh water availability of less than $1700 \mathrm{~m} 3$ per capita (the index for water stress), the current estimation by FAO is $1154 \mathrm{~m} 3$ per capita per year. According to the International Water Management Institute (IWMI, 1996), in 2025 South Africa will be among the countries that will experience a physical water scarcity with an annual freshwater availability of less than $1000 \mathrm{~m} 3$ per capita (the index for water scarcity). South Africa is also considered as a semi-arid country (65\% of the country) with an average rainfall of $450 \mathrm{~mm}$ per year. This is below the world average of about $860 \mathrm{~mm}$ per year, therefore, South Africa's water resources are in global terms, scarce and limited in extent (RSA, 2002). This situation may have a severe impact on various key sectors of the economy such as agriculture and manufacturing which are amongst the big users of water. For that reason, there is a need for new strategies regarding the efficient use of water domestically and industrially, harvesting rainwater, recycling domestic and industrial wastewaters at low costs. This will aim to maximize and assure to availability of water resources in the country. AMD represents also a great opportunity to increase volume of water resources needed in the country because if treated efficiently it can contribute positively to trim down the challenge of water scarcity in the country. The volume of AMD 
rejected per day by South African mines is very high. A classic example for illustration, the potential volume of AMD for the Witwatersrand Goldfield alone amounts to an estimated 350Ml/day (CSIR, 2009). It represents $10 \%$ of the potable water supplied daily by Rand Water to municipal authorities for urban distribution in Gauteng province and surrounding areas, at a cost of R3000/Ml. These figures place not only the volume, but also the potential economic value of the mine water in perspective (CSIR, 2009).

\section{Treatment Methods for Acid Mine Drainage}

Treatment methods for AMD can be categorized into passive and active treatments. Passive treatment is when mine water is passed through an environment where geochemical and biological processes help to improve the quality of the mine water and require relatively little resource input once in operation (Humphries et al., 2017). Passive systems present an advantage of being self-sustaining with sporadic maintenance, very low operating and capital costs but the quality of effluent is being poorer. They are mainly applied in cases of low flow rates, acidity, metal, sulphate removal (Humphries et al., 2017). Active treatment is when the water is treated in a constructed plant were processes are controlled and require continuous input of resources to sustain the process. The range of application is adapted to all flow rates especially high flow rates. Though operating and capital costs can be higher, the quality of effluent is very high with some potential for cost recovery by the sale of product water, metals and by-products, and this can be considered as a great advantage over passive treatments (Nleya et al., 2016). Conversely, they require the use of chemicals, operations and maintenance staff, they require electrical and mechanical sources to perform efficiently. The types of active treatment include biological treatment, chemical treatment, membrane technology and ion exchange.

Table 1 presents the categories of AMD treatment options, some of these methods are discussed in this review. 
Table 1. Generic range of AMD treatment technologies

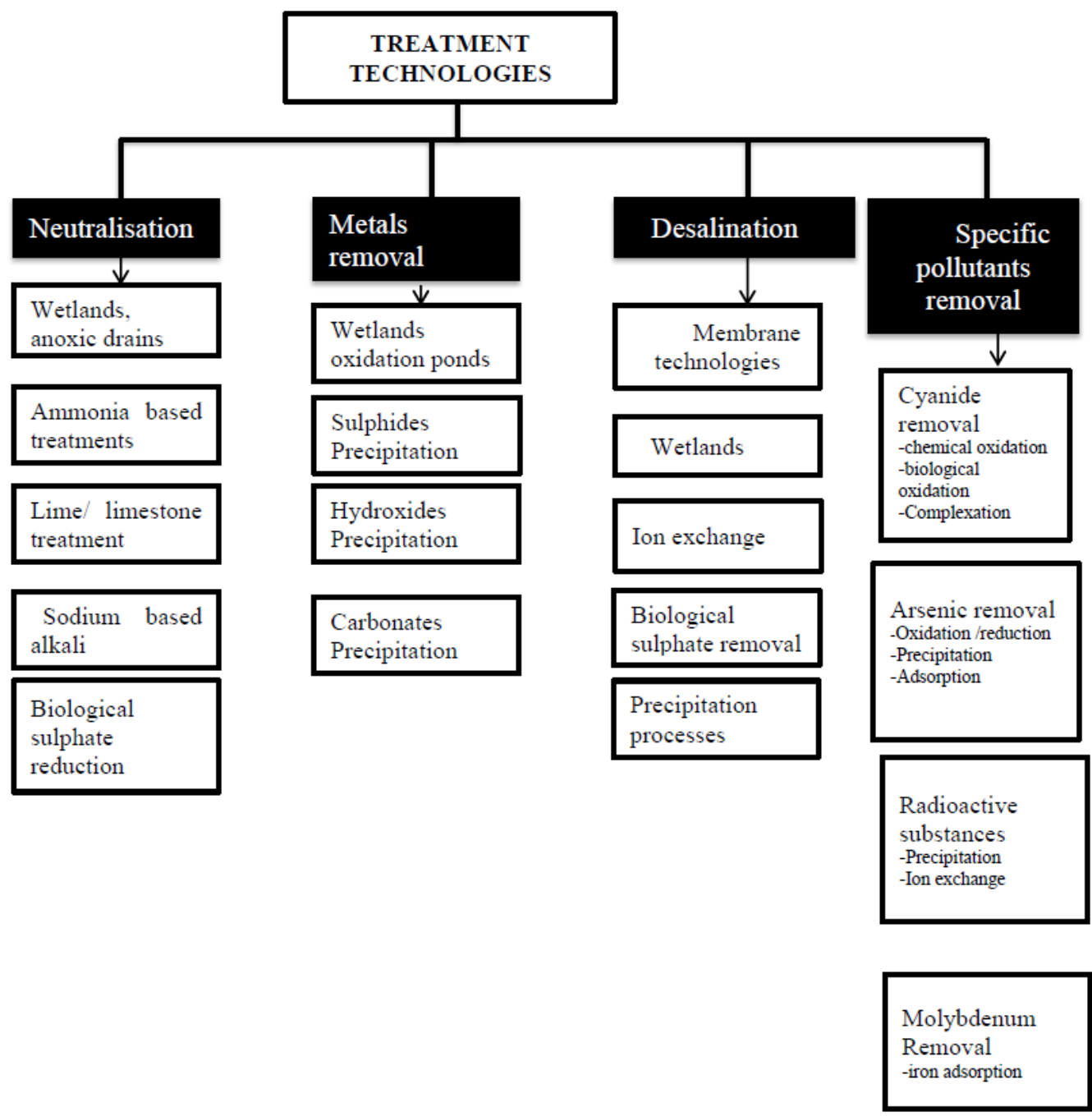

\subsection{Combined Chemical and Biological Treatment}

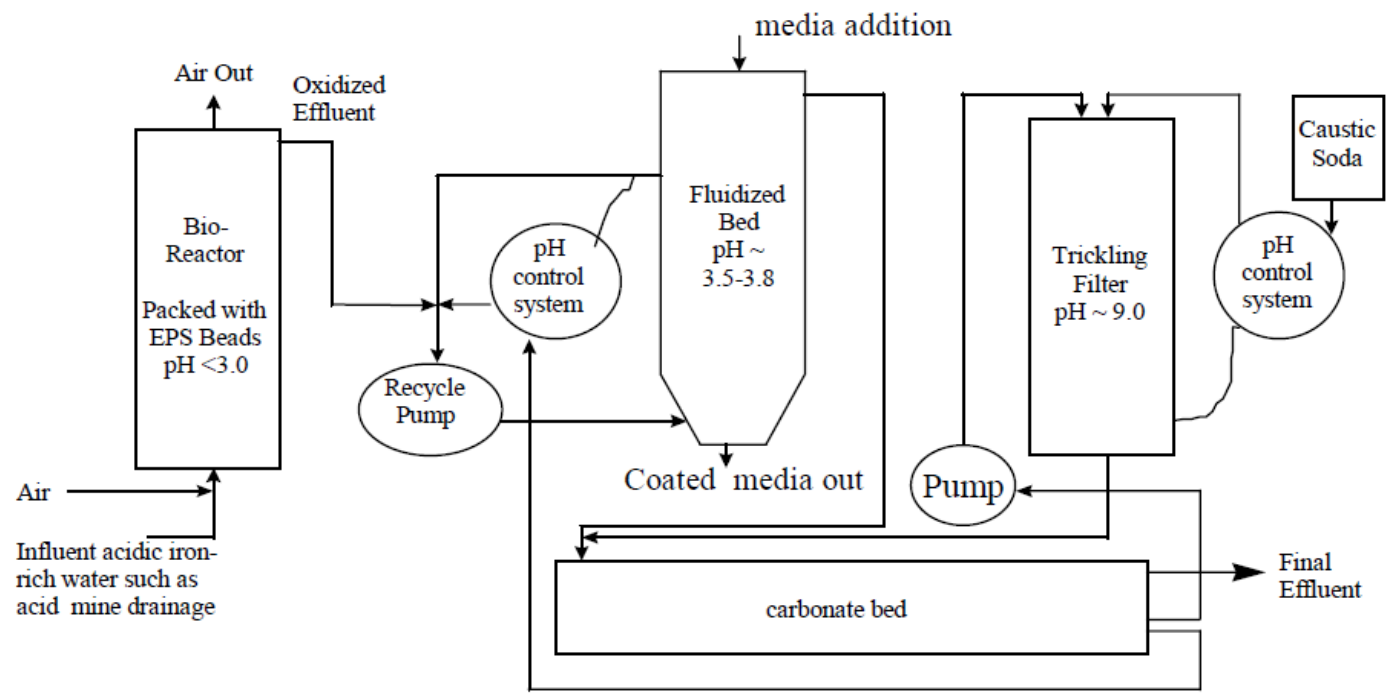

Figure 2. Schematic of chemical and biological treatment of acid mine drainage 
This patented process represented in Figure 2 involves the oxidation of ferrous iron in a bioreactor that is designed as a packed bed. Afterwards the iron is precipitated within a bed that is fluidized then manganese and other heavy metals such as nickel, zinc, and copper are removed in a trickling filter at a high $\mathrm{pH}$ greater than 9 with the last step being the neutralization in a bed of carbonate. This procedure does not generate iron oxyhydroxide sludge (Diz, 1997). It is focused on ferric oxyhydroxide surface precipitation which begins by the bio-oxidation of ferrous iron to ferric iron at a low $\mathrm{pH}$. The oxidized iron solution which is acidic is then circulated through a bed that is fluidized in a way which promotes surface precipitation while at the same time avoiding the generation of very small iron particles which are unwanted (Diz, 1997). The precipitation reactor has a limestone or dolomite bed which is the primary source of alkalinity to adjust the $\mathrm{pH}$ through which the effluent from the fluidized bed is circulated. This is achieved in order to raise the $\mathrm{pH}$ before it is re-injected into the fluidized bed. The water that is now free of iron is then re-circulated separately through a trickling filter where modest amounts of concentrated caustic soda are added to oxidize and precipitate manganese. The bioreactor is also designed to reduce ferric iron which is regenerated from a solution of ferrous sulphate to ferrous iron (Diz, 1997). About 98\% of iron is removed in this fluidized bed with the concentration of iron in the effluent being below $10 \mathrm{mg} / \mathrm{L}$. Also, the removal efficiencies ranged from 70 to $97 \%$ at $\mathrm{pH}$ greater than 9 (at which oxidation occurs) for zinc, copper, nickel. The effluent from this process is free of iron and the process does not generate iron sludge. This process is most suitable for treatment of acid mine drainage (Diz, 1997). The weakness of this process is that it could require more use of energy for aeration; it also requires regular maintenance and monitoring. Therefore, operating costs will be increased.

\subsection{Lime Neutralization Treatment}

This method is also effective for AMD treatment, with the first step which is lime neutralization or precipitation. AMD is added to a rapid mix chamber which has hydrated lime either in slurry or a dry form. If the concentration of ferrous iron is lower than $50 \mathrm{mg} / \mathrm{L}$, it is treated by adding an alkaline to make the $\mathrm{pH}$ between 6.5 and 8.0 then it is directed to a settling chamber. Higher concentrations of ferrous iron have a $\mathrm{pH}$ that is already at this range. AMD is then passed through an aeration tank which converts ferrous hydroxide precipitate to ferric hydroxide which is then directed to a settling chamber where the heavy metal precipitate out of the solution (Akcil and Koldas, 2006). Raising the $\mathrm{pH}$ of the AMD significantly reduces the number of iron oxidizing bacteria since they do not thrive at this $\mathrm{pH}$ which reduce the rate of generation of acid (Akcil and Koldas, 2006,). Limestone is rarely used because it does not raise the $\mathrm{pH}$ of the solution above 6.0 and also since it is inefficient with water that has high ferrous iron concentration. In addition, the method using limestone is more complex than the one using lime. As a result, lime is commonly used. The simplest neutralization method is achieved by lining a streambed with limestone. In this way, the AMD is treated as it passes over the limestone. This strategy is, however, not effective since the limestone can easily become coated with iron. Biological growth and calcium sulphate inhibits it from interacting with the mine water, in this case lime is more efficient (Akcil and Koldas, 2006,). A novel integrated limestone/lime neutralization process was developed at the 
South African Council for Scientific and Industrial Research (Geldenhuys et al., 2001). The integrated limestone/lime process involves a pre-neutralization using cheap limestone as a first step. The pre-neutralization is followed by lime neutralization to reach a targeted $\mathrm{pH}$, which is dictated by the treatment targets such as specific metals removal (This step is also designed to precipitate gypsum). Finally, a re-carbonation and $\mathrm{pH}$ adjustment process using the $\mathrm{CO}_{2}$ generated in the first process step (Geldenhuys et al., 2001). The strength of this process relate to the efficient use of relatively inexpensive alkali materials and reuse of alkali sludge produced in the process. However, its weaknesses could be the clogging of pipes and armouring precipitation of ferric hydroxide on the limestone which otherwise severely reduces the effectiveness of the neutralizing agent.

\subsection{Chemical Precipitation for Sulphates Removal}

Mine water may contain a wide range of anionic species, but sulphate is typical of many mine drainages and frequently represents the main contaminant. Therefore, sulphate removal is an important treatment objective and is also often a key to the reduction of total dissolved solids (TDS). Some sulphate is removed by gypsum precipitation during neutralization if lime, limestone, or another calcium source is added throughout the treatment process. In addition, a number of precipitation processes have been developed for specific application to high sulphate content mine waters, including the following: Barium sulphate process, Ettringite $\left(\mathrm{Ca}_{6} \mathrm{Al}_{2}\left(\mathrm{SO}_{4}\right)_{3}(\mathrm{OH})_{12} .26 \mathrm{H}_{2} \mathrm{O}\right)$ precipitation process, and SAVMIN process. The barium sulphate process is based on the addition of a barium salt to re-precipitate sulphate. The insoluble barium sulphate sludge is separated and removed from the main stream process. The barium sulphate process has been limited only on pilot scale demonstration processes.

While this process is very effective, it is challenged by the use of an environmentally toxic compound as a treatment reagent (barium salt), the generation and handling of a toxic and hazardous gas $\left(\mathrm{H}_{2} \mathrm{~S}\right)$, the requirement for thermal regeneration and recycle of the barium reagent. The Ettringite process is based on the addition of aluminium hydroxide in a high $\mathrm{pH}$ environment resulting in precipitation of Ettringite (a hydrated calcium aluminosulphate mineral), as shown in equation 5 :

$$
6 \mathrm{Ca}^{2+}+3 \mathrm{SO}_{4}{ }^{2-}+2 \mathrm{Al}(\mathrm{OH})_{3}+38 \mathrm{H}_{2} \mathrm{O}=\mathrm{Ca}_{6} \mathrm{Al}_{2}\left(\mathrm{SO}_{4}\right)_{3}(\mathrm{OH})_{12} \cdot 26 \mathrm{H}_{2} \mathrm{O}+6 \mathrm{H}_{3} \mathrm{O}
$$

SAVIMN process uses the precipitation processes in successive stages to remove dissolved $\mathrm{SO}_{4}{ }^{2-}$ and metals from mine water (Smit, 1999). During Stage 1, lime is added to raise the $\mathrm{pH}$ to values greater than 11 . This allows the precipitation of metal hydroxides. The metal hydroxides are removed and the remaining water is supersaturated with respect to gypsum. In stage 2, the supersaturated solution is seeded with gypsum to catalyse the precipitation of gypsum. The precipitated gypsum is removed from water and water from this stage is saturated with respect to gypsum. The concentrations of $\mathrm{SO}_{4}{ }^{2-}$ ions are still above the required limit of $500 \mathrm{ppm}$. About stage 3, Aluminium hydroxide is added to the water which is saturated with respect to gypsum, this results in precipitation of Ettringite. Concerning stage 4 , the water from stage 3 (pH 12 and dissolved $\mathrm{SO}_{4}{ }^{2-}<200 \mathrm{ppm}$ ) is treated with $\mathrm{CO}_{2}$. This results in $\mathrm{CaCO}_{3}$ precipitation which is relatively pure. The water produced has a $\mathrm{pH}$ of 
8 and contains dissolved $\mathrm{SO}_{4}{ }^{2-}<200 \mathrm{ppm}$.

Finally, in stage 5 Ettringite is decomposed by addition of sulphuric acid to regenerate $\mathrm{Al}(\mathrm{OH})_{3}$. The $\mathrm{Al}(\mathrm{OH})_{3}$ is recycled and used again in stage 3. The remaining water after removing $\mathrm{Al}(\mathrm{OH})_{3}$ is seeded with gypsum to catalyse the precipitation of gypsum since the solution is still saturated with respect to gypsum. The resultant water is saturated with respect to gypsum and is returned back to stage 3 for Ettringite precipitation. The product water from this process contains $\mathrm{SO}_{4}{ }^{2-}$ below $200 \mathrm{ppm}$ and the metal content is below the required effluent limit.

\subsection{Biological Sulphates Removal}

The main process takes place in a bioreactor. The bioreactor uses the biogenic production of hydrogen sulphide to generate alkalinity and remove metals as insoluble sulphides. This is one of the processes that occur in compost bioreactors. Sulphate reducing bacteria (SRB) are used in these reactors which are very sensitive to acidity (even to moderate acidity) (Le Pape et al., 2017). For the process to run optimally, additional alkali may be required a part from the one produced by the SRB. In this case the alkali will be added in chemical form. The process uses microbiological population and processes for conversion of sulphates to sulphides by SRB. Also, the precipitation of metal sulphides and conversion of any excess $\mathrm{H}_{2} \mathrm{~S}$ produced to elemental sulphur using sulphide-oxidizing bacteria is part of the process (Le Pape et al., 2017). The general key features of the biological sulphate removal process include the pre-treatment to remove metals by precipitation as sulphides, hydroxides, or carbonates, the dosing of an electron donor and carbon source such as alcohol, sugar, $\mathrm{H}_{2}$ gas, and even complex substrates such as sewage sludge, the addition of nutrients, including sources of nitrogen, phosphate, potassium, and trace minerals and sulphate reduction in an anaerobic reactor which converts sulphates to sulphides. The advantages of this technology are high removal of heavy metals, stable and small sludge production, very high water recovery ( about 98\%) and low operation costs (for anaerobic process only) ( Le Pape et al., 2017)

The weaknesses of the technology are sensitivity to environmental conditions such as temperature, acidity and $\mathrm{pH}$, dependency on carbon dosing source, not able to adapt to fluctuating feed water quality, also the capital ( for both anaerobic and aerobic systems) and operational costs (aerobic systems) of these systems are significant ( Le Pape et al., 2017).

\subsection{Sulphides Precipitation}

The precipitation reaction is generally conducted under alkaline conditions to promote sulphide ion formation. Once the precipitation reaction is completed, metal-sulphide precipitates must be physically removed from solution (through coagulation, flocculation, and clarification, or filtration) leaving metal-sulphide sludge (Nordstrom et al., 2017; Perez et a., 2016; Simate, 2017). Sulphides precipitation is sometimes used in water treatment following conventional lime treatment to reduce concentrations of residual metals, particularly cadmium. This is successful because of the ability of sulphides in reducing metal concentrations at lower values than can be achieved by precipitating metals as hydroxides 
with lime, although the metals precipitated are not recovered as they report to the lime sludge. (Nordstrom et al., 2017; Perez et al., 2016; Simate, 2017). Some of the advantages of sulphides treatment include effective metal removals for most metals, low retention time requirement, and reduced sludge volumes (Nordstrom et al., 2017; Perez et a., 2016; Le Pape et al., 2017; Simate , 2017 )

The weaknesses of sulphides treatment are significant and include potential for toxic hydrogen sulphide gas emissions and residual sulphides in treatment of effluents. Also, the soluble sulphides process may result in smell problems and the complexities of the systems frequently result in higher capital and operating costs than lime treatment.

\subsection{Membrane Technologies}

A wide range of membrane treatment methods can be used to treat AMD, however the biggest challenge with membrane technologies is scaling and fouling but also membrane technologies can be energy intensive because of the use of high pressure for separation of water and brine. Membrane treatments can be classified as secondary processes for treatment of mine water (Ambiado et al., 2017). Membrane systems require pre-treatment of mine water to remove suspended solids to reduce fouling of membranes. With membrane processes AMD goes first through neutralization to adjust the $\mathrm{pH}$. To avoid scaling of the membrane due to the presence of calcium and magnesium in mine waters, softening is implemented before microfiltration and/or ultrafiltration process steps. The polishing step to get high quality clean water is achieved through reverse osmosis which also a membrane based process (Ambiado et al., 2017)

The treated water is free from colloids and microorganisms, but still contains solutes. Ultrafiltration and microfiltration can be used as pre-treatment options for nanofiltration and reverse osmosis (RO) treatment of mine water to produce drinking water (Kentish and Stevens, 2001). Membranes technology is very successful because of high removal efficiencies of heavy metals and others pollutants (Ambiado et al., 2017). There is a way to overcome this challenge should membrane cleaning process being achieved with water at high pressure toward the back of the membrane (Ambiado, et al., 2017). Currently, many improvements have been recorded regarding the use membrane technologies, low pressure and anti-fouling membranes have been developed to overcome the challenges related to fouling and energy consumption. This could contribute at large extent in the treatment of AMD because of the quality effluent generated after the treatment and the reduced operating costs in case these membranes van be used at large scale.

\subsection{Ion Exchange}

The process of ion exchange can be defined as the reversible interchange of a charged ion (cation or anion) for a similarly charged ion, between a solid material (the ion exchanger) and the surrounding liquid in which there is no permanent change in the structure of the solid. Ion exchange is similar to sorption, such that in both cases, a dissolved species is taken up by a solid; however, the characteristic difference between the two phenomena is that ion exchange, unlike sorption, is a stoichiometric process where every ion which is removed from the 
solution is replaced by an equivalent amount of another species of the same sign. In sorption, on the other hand, a solute is taken up without being replaced by another species.

This process has high sulphates and heavy metals removal efficiencies but requires high chemical dosing (Sephton and Webb, 2017). It was mostly used on pilot scales than large commercial plants. Also, the process performance and resin recovery is sometimes subject to interference. A number of natural ion-exchange materials, such as zeolites (a class of aluminosilicate minerals), have been demonstrated to have treatment potential for AMD (Sephton and Webb, 2017). A novel ion exchange process named GYPCIX was developed and used on small scales only for high sulphate type mine drainage. The process requires pre-treatment to remove metals, which may interfere and decrease the efficiency of the downstream ion exchange process resins. The cation resin exchanges $\mathrm{Ca}^{2+}, \mathrm{Mg}^{2+}$, and other cations (i.e., metal ions) are achieved through equation 6 and 7:

$$
2 \mathrm{R}-\mathrm{H}+\mathrm{Ca}^{2+} \rightarrow \mathrm{R}_{2} \mathrm{Ca}+2 \mathrm{H}^{+}
$$

In this equation the product water is acidified in this first process and requires degassing of $\mathrm{CO}_{2}$

The anion resin exchanges $\mathrm{SO}_{4}{ }^{2-}, \mathrm{Cl}^{-}$, and other anions by the following reaction:

$$
2 \mathrm{R}-\mathrm{OH}+\mathrm{SO}_{4}{ }^{2-} \rightarrow \mathrm{R}_{2} \mathrm{SO}_{4}+2 \mathrm{OH}^{-}
$$

Here the product water is near neutral and might require stabilization before distribution or discharge. The resin regeneration requires sulphuric acid and lime, thus producing mainly gypsum as waste sludge.

\subsection{Fly Ash Treatment of AMD}

AMD remediation can be very costly and challenging to achieve due to the high costs of chemicals and storage of high volumes of sludge produced during chemical treatment. Therefore, alternative low costs liming substitutes are constantly being hunted. Such substitutes should be readily available, economically feasible and produce less problematic sludge. Studies have also shown that addition of fly ash (FA) to AMD results in acid neutralization, metal retention and therefore, the improvement of the leachate quality (Gitari et al., 2006; Prasad and Kumar, 2016; Orakwue et al., 2016 ).

FA is capable of neutralizing AMD and precipitating metals and $\mathrm{SO}_{4}{ }^{2-}$ ions as hydroxides and gypsum respectively. This is because FA contains free lime that leaches out when mixed with mine water (Gitari et al., 2006; Prasad and Kumar, 2016; Orakwue et al., 2016). It was reported that treatment of acid mine water rich in $\mathrm{Fe}$ and $\mathrm{Al}$ results in removal of metals to below detection limit while sulphates can be removed to equilibrium saturation point of about $2000 \mathrm{ppm}$. FA can be used to treat mine water for the removal of most contaminants from the Fe-Al rich and $\mathrm{Ca}-\mathrm{Mg}$ mine waters (Prasad and Kumar, 2016; Orakwue et al., 2016). Elements such as $\mathrm{K}, \mathrm{Na}, \mathrm{Ti}, \mathrm{V}, \mathrm{Cu}$, As, $\mathrm{Se}, \mathrm{B}, \mathrm{Ba}, \mathrm{Pb}$ and $\mathrm{Si}$ leach from FA during treatment of mine water with FA to levels below the allowed limits for potable water in South Africa. This process is promising in terms of removal of $\mathrm{SO}_{4}{ }^{2-}$ and metals. However, most studies on 
FA treatment of mine water were completed on laboratory levels. The weakness of this process could be the production of large amounts of sludge including environmental and health related problems caused by some heavy metals present in fly ash such as arsenic and cadmium.

\subsection{Aeration}

Aeration can be achieved before or during treatment, using gravity or mechanical aeration (or mixing) devices (Water, 2016). Since the principal contaminant is often dissolved ferrous iron, a key aspect of treating AMD is aeration. Only about $10 \mathrm{mg} / \mathrm{l}$ of oxygen can dissolve in water, so if there is more than about $50 \mathrm{mg} / \mathrm{l}$ of $\mathrm{Fe}^{2+}$, the water must be aerated (Water, 2016). Even at lower $\mathrm{Fe}^{2+}$ concentrations, aeration increases the level of dissolved oxygen and promotes oxidation of iron and manganese, increases chemical treatment efficiency, and decreases costs related to the use of chemicals. Aeration also drives off dissolved $\mathrm{CO}_{2}$, which is commonly present in mine water coming from underground (Water, 2016). This situation increases the $\mathrm{pH}$ and can significantly reduce reagent use. Despite some advantages as mentioned earlier, the biggest weakness of aeration is operating costs related to energy needed for the process to produce oxygen for the aeration process to be effective.

\subsection{Microalgae Treatment of AMD}

Algae species such as spirulina sp, chlorella, Scenedesmus, cladophora, oscillatoria, anabaena, $P$. tricornutum, and euglena gracillis have shown a great potential and the capacity to remove at large extent heavy metals from AMD. They act as "hyper-accumulators" and "hyper-absorbents" with a high selectivity for different elements (Bwapwa et al., 2017). They have an appetite for pollutants such as phosphorus, heavy metals and even silver nanoparticles (more especially for euglena gracillis). The use of these strains could have a significant impact on exiting and former mining sites around the world (Adey et al., 1996 Bwapwa et al., 2017). Also, they generate high alkalinity that is essential for precipitation of heavy metals to occur in AMD during treatment. However, algae based methods are not the ultimate solution to the problem, there is still room for more studies (Kalin et al., 2006; Bwapwa et al., 2017).

\section{Conclusions}

Management and treatment of acid mine drainage are undertaken to reduce its impact on the environment. In order to make management and treatment strategies successful, the first step is to ensure that groundwater and surface runoff do not come into contact with the acid mine effluent thus preventing its seepage into the environment. Pumping or drainage of AMD from the mines to the treatment has to be done in a very controlled manner. Concrete material for pipes and drain can be used to channel AMD to treatment site.

On treatment site, the storage of AMD has to be undertaken in such a way that no diversion and infiltration in the environment can occur. The control of level of water in mines voids need to be monitored to reduce seismic activity. However, management strategies can only be effective with adequate financial resources. In this case mining entities and government institutions will have to find a working strategy with a consistent financial model to help 
manage AMD related issues such as the control and management of abandoned mines.

In terms of treatment processes, combined chemical and biological process is focused on precipitating ferric oxyhydroxide on the surface without generating iron oxyhydroxide sludge. Removal efficiencies ranging from $70 \%$ to $98 \%$ can be achieved regarding heavy metal such as iron, zinc, nickel, copper and manganese. These metals are removed in the fluidized bed and the trickling filter through precipitation and sorption onto the oxide surfaces. This method is suitable for treatment of acid mine drainage looking at its performance. However, it requires maintenance and use electrical power for the aeration.

Neutralization process is also used to treat AMD, though clogging of pipes by sludge may occur, it is an effective process with cheap alkali materials and reuse of sludge in the process. In this method lime is used to adjust the $\mathrm{pH}$ of the acid mine drainage (which is very low) in order to precipitate iron and heavy metals.

Chemical precipitation process uses chemicals to remove sulphates by precipitation. In general, chemical removal find its application to high metals and high sulphate mine waters, with high water recovery (about 95\%), it has been proven with many demonstration scales, mostly large commercial plants. However, the operating costs are higher due to the uses of chemicals and high amount of generated sludge. Regarding the biological sulphates removal process, high water recovery can be recorded (about 98\%) but very sensitive to environmental conditions such as acidity, temperature and $\mathrm{pH}$. It uses microbiological populations and processes to convert sulphates to sulphides with the help of sulphate reducing bacteria. Sulphides precipitation process is also used to treat AMD with sulphide precipitating agents added to AMD. Despite some setbacks mentioned earlier, the method can be used to remove efficiently a certain number of metals under alkaline conditions, at low retention time, with reduced sludge volumes.

Membrane technologies are also a viable option to treat AMD, especially if high quality of treated water is expected. AMD goes through neutralisation, softening, microfiltration; ultrafiltration, nanofiltration or reverse osmosis to get a quality of treated which is very high. Water recovery is about $90 \%$, however, the main setback of the process is membranes fouling.

A method such as Ion exchange using cationic and anionic resins to remove dissolved species, the aeration method using oxygen from air to oxidise iron and manganese and Coal fly ash process used for the precipitation of $\mathrm{Fe}, \mathrm{Al}$, $\mathrm{As}$ and $\mathrm{Pb}$, are showing a huge potential to treat AMD despite some setbacks related to operating and capital costs. Briefly, AMD can be seen as an opportunity to fix the challenge of water scarcity in South Africa providing that efficient treatment processes are used.

Modeling and optimisation studies of various processes should be undertaken to improve on the treatment strategies. Despite some few setbacks related to operating costs, capital costs and environmental aspects, processes such as membrane technologies, chemical and biological removal have been proven satisfactory regarding water recovery and water quality for many large and commercial plants worldwide, they are potentially suitable for AMD 
treatment in South Africa.

From this analysis, it is suggested that Membranes technologies can be suitable for producing drinking water from AMD, biological and chemical methods applied on AMD can serve for others application such as irrigation and manufacturing. Briefly, it is important to emphasis on the fact that AMD is a global problem, more especially in the developing world where cleanup and remediation activities are neglected because of their high cost and low return. By making the cleanup process pay for itself, both the health and the environment of millions of people around the world can be improved.

\section{Acknowledgements}

The author wishes to acknowledge the research directorate from his institution for the support

\section{References}

Akcil, A., \& Koldas, S. (2006). Acid Mine Drainage (AMD): causes, treatment and case studies. Journal of Cleaner Production, 14, 1139-1145.

https://doi.org/10.1016/j.jclepro.2004.09.006_

Adey, W. H., Luckett, C., \& Smith, M. (1996). Purification of industrially contaminated groundwaters using controlled ecosystems. Ecological Engineering, 7(3), 191-212.

Ambiado, K., Bustos, C., Schwarz, A., \& Bórquez, R. (2017). Membrane technology applied to acid mine drainage from copper mining. Water Science and Technology, 75(3), 705-715. https://doi.org/10.2166/wst.2016.556

ANZMEC. (1995) Baseline environmental guidelines for new and existing mines. Australia and New Zealand Minerals and Energy Council (ANZMEC). Report 95.02, March, Canberra

Bell, F. G., Bullock, S. E. T., Hälbich, T. F. J., \& Lindsay, P. (2001). Environmental impacts associated with an abandoned mine in the Witbank Coalfield, South Africa. International Journal of Coal Geology, 45(2), 195-216. https://doi.org/10.1016/S0166-5162(00)00033-1_

Bigham, J. M., \& Cravotta, C. A. (2016). Acid mine drainage." (2016), 6-10.

Bwapwa, J. K., Jaiyeola, A. T., \& Chetty, R. (2017). Bioremediation of acid mine drainage using algae strains: A review. South African Journal of Chemical Engineering, 24, 62-70.

Chen, L. X., Huang, L. N., Méndez-García, C., Kuang, J. L., Hua, Z. S., Liu, J., \& Shu, W. S. (2016). Microbial communities, processes and functions in acid mine drainage ecosystems. Current opinion in biotechnology, 38, 150-158.

https://doi.org/10.1016/j.copbio.2016.01.013

Council for Scientific and Industrial Research (CSIR) ( 2009) : Acid mine drainage in South Africa, Briefing note, 2009/02, August 2009 , South Africa

Demers, I., Mbonimpa, M., Benzaazoua, M., Bouda, M., Awoh, S., Lortie, S., \& Gagnon, M. (2017). Use of acid mine drainage treatment sludge by combination with a natural soil as an oxygen barrier cover for mine waste reclamation: Laboratory column tests and intermediate 
scale field tests. Minerals Engineering, 107, 43-52.

https://doi.org/10.1016/j.mineng.2016.11.017_

Diz, H. R. (1997). Chemical and biological treatment of acid mine drainage for the removal of heavy metals and acidity (Doctoral dissertation).

Department of Water Affairs and Forestry (DWAF) (2006) Best Practice Guidelines for Water

Förstner, U., \& Kersten, M. (1988). Assessment of metal mobility in dredged material and mine waste by pore water chemistry and solid speciation. In Chemistry and biology of solid waste (pp. 214-237). Springer Berlin Heidelberg.

Fernandes, A. C. P. (2016). Waste Management in the Scope of a Gold Mine Project-Prediction of Acid drainage and Study of Mitigation Solutions.

Geldenhuys, P. (2003). An integrated limestone/lime process for partial sulphate removal. Journal of the Southern African Institute of Mining and Metallurgy, 103(6), 345-353.

Gitari, M. W., Petrik, L. F., Etchebers, O., Key, D. L., Iwuoha, E., \& Okujeni, C. (2006). Treatment of acid mine drainage with fly ash: removal of major contaminants and trace elements. Journal of Environmental Science and Health Part A, 41(8), 1729-1747.. https://doi.org/10.1080/10934520600754425

International water management institute (IWMI) (1996) : World Water Demand and Supply, 1990 to 2025: Scenarios and Issues, Research Report 19.

Jennings, S. R., Neuman, D. R., \& Blicker, P. S. (2008). Acid mine drainage and effects on fish health and ecology: a review. Reclam Res Group Publ, Bozeman, MT.

Kefeni, K. K., Msagati, T. A., \& Mamba, B. B. (2017). Acid mine drainage: Prevention, treatment options, and resource recovery: A review. Journal of Cleaner Production. https://doi.org/10.1016/j.fuel.2016.10.018_

Humphries, M. S., McCarthy, T. S., \& Pillay, L. (2017). Attenuation of pollution arising from acid mine drainage by a natural wetland on the Witwatersrand. South African Journal of Science, 113(1-2), 1-9. .https://doi.org/10.17159/sajs.2017/20160237

Kalin, M., Fyson, A., \& Wheeler, W. N. (2006). The chemistry of conventional and alternative treatment systems for the neutralization of acid mine drainage. Science of the Total Environment, 366(2), 395-408.

Kentish, S.E. \& Stevens, G.W. (2001). Innovations in separations technology for the recycling and re- use of liquid waste streams, Chemical Engineering Journal, 84(2), 149-159. https://doi.org/10.1016/S1385-8947(01)00199-1

Kuang, J., Huang, L., He, Z., Chen, L., Hua, Z., Jia, P., \& Shu, W. (2016). Predicting taxonomic and functional structure of microbial communities in acid mine drainage. The ISME journal, 10(6), 1527. https://doi.org/10.1038/ismej.2015.201 
Lauzon, Shelly (Woods Hole Oceanographic Institution). (2002, March). New Iron Eating Microbe Major Component of Mining Pollution and Iron and Sulfur Cycling. Available at: http://www.whoi.edu/media/IronEatingMicrobe.html_PMCid:PMC127171

Le Pape, P., Battaglia-Brunet, F., Parmentier, M., Joulian, C., Gassaud, C., Fernandez-Rojo, L., \& Casiot, C. (2017). Complete removal of arsenic and zinc from a heavily contaminated acid mine drainage via an indigenous SRB consortium. Journal of hazardous materials, 321, 764-772. https://doi.org/10.1016/j.jhazmat.2016.09.06_PMid: 27720469

Macías, F., Pérez-López, R., Caraballo, M. A., Cánovas, C. R., \& Nieto, J. M. (2017). Management strategies and valorization for waste sludge from active treatment of extremely metal-polluted acid mine drainage: A contribution for sustainable mining. Journal of Cleaner Production, 141, 1057-1066. https://doi.org/10.1016/j.jclepro.2016.09.181

MEND (1995) Economic evaluation of acid mine drainage technologies, MEND Report 5.8.1, Energy Mines and Resources Canada, January, Ottawa.

Mühling, M., Poehlein, A., Stuhr, A., Voitel, M., Daniel, R., \& Schlömann, M. (2016). Reconstruction of the Metabolic Potential of Acidophilic Sideroxydans Strains from the Metagenome of an Microaerophilic Enrichment Culture of Acidophilic Iron-Oxidizing Bacteria from a Pilot Plant for the Treatment of Acid Mine Drainage Reveals Metabolic Versatility and Adaptation to Life at Low pH. Frontiers in microbiology, 7. https://doi.org/10.3389/fmicb.2016.02082

Naidoo, S. (2017). The Nature of Acid Mine Drainage in the Vaal River System. In Acid Mine Drainage in South Africa (pp. 41-73). Springer International Publishing. https://doi.org/10.1007/978-3-319-44435-2_4

Nleya, Y., Simate, G. S., \& Ndlovu, S. (2016). Sustainability assessment of the recovery and utilisation of acid from acid mine drainage. Journal of Cleaner Production, 113, 17-27. https://doi.org/10.1016/j.jclepro.2015.11.005_

Nordstrom, D. K., Bowell, R. J., Campbell, K. M., \& Alpers, C. N. (2017). Challenges in Recovering Resources from Acid Mine Drainage. In IMWA 2017 (pp. 1138-1146).

Office of Surface Mining (2006) "Surface Mining Law." from http://www.osmre.gov/smcra.htm.

Orakwue, E. O., Asokbunyarat, V., Rene, E. R., Lens, P. N., \& Annachhatre, A. (2016). Adsorption of Iron (II) from Acid Mine Drainage Contaminated Groundwater Using Coal Fly Ash, Coal Bottom Ash, and Bentonite Clay. Water, Air, \& Soil Pollution, 227(3), 74. https://doi.org/10.1007/s11270-016-2772-8_

Pak, G., Jung, M., Kim, H., Mallari, K. J. B., Chung, G., Kim, S., \& Yoon, J. (2016). Assessment of Metals Loading in an Acid Mine Drainage Watershed. Mine Water and the Environment, 35(1), 44-54. https://doi.org/10.1007/s10230-015-0336-6_

Pérez, N., Schwarz, A., Sanhueza, P., \& Chaparro, G. (2016). Performance of three bench-scale diffusive exchange systems during treatment of acid mine drainage with high 


\section{Macrothink \\ Environmental Management and Sustainable Development \\ ISSN 2164-7682 2018, Vol. 7, No. 1}

copper concentration. Desalination and Water Treatment.

Prasad, B., \& Kumar, H. (2016). Treatment of acid mine drainage using a fly ash zeolite column. Mine Water and the Environment, 35(4), 553-557.

https://doi.org/10.1007/s10230-015-0373-1_

Republic of South Africa (2002): Proposed First Edition of National Water Resource Strategy. Review of water resources statistics by country. Viewed on http://www.fao.org/ag/agl/aglw/aquastat/water_res/south_africa/index.stm_

Sephton, M. G., \& Webb, J. A. (2017). Application of Portland cement to control acid mine drainage generation from waste rocks. Applied Geochemistry, 81, 143-154.. https://doi.org/10.1016/j.apgeochem.2017.03.017_

Simate, G. S. (2017). Mathematical Modelling in Acid Mine Drainage. Management and Mitigation of Acid Mine Drainage in South Africa: Input for Mineral Beneficiation in Africa, p.149.

Smit, J. P. (1999). The purification of polluted mine water, International symposium of Mine Water \& Environment for the 21st Century Seville, Spain

U.S. Environmental Protection Agency USEPA (1995) Mining metallic ores and minerals Technical Support Document, International Training Workshop, Principles of Environmental Enforcement

Water, M. (2016). Dealing with Acid Mine Drainage. Environmental Management. Available at http://hdl.handle.net/10520/EJC185033, New Media Publishing

\section{Copyright Disclaimer}

Copyright for this article is retained by the author(s), with first publication rights granted to the journal.

This is an open-access article distributed under the terms and conditions of the Creative Commons Attribution license (http://creativecommons.org/licenses/by/3.0/). 